\title{
In vitro antimicrobial effect and in vivo preventive and therapeutic effects of partially purified lantibiotic lacticin NK34 against infection by Staphylococcus species isolated from bovine mastitis
}

\author{
S. Y. Kim, ${ }^{*}$ S. Shin, ${ }^{*}$ H. C. Koo, ${ }^{* 1}$ J.-H. Youn, ${ }^{*}$ H.-D. Paik, $†$ and Y. H. Park* ${ }^{* 1}$ \\ *Department of Microbiology, College of Veterinary Medicine and BK21 Program for Veterinary Science, Seoul National University, Seoul 151-742, \\ Korea \\ †Department of Food Science and Biotechnology of Animal Resources, Konkuk University, Seoul 143-701, Korea
}

\section{ABSTRACT}

Lantibiotics are small $(<5 \mathrm{kDa})$, polycyclic peptides produced by gram-positive bacteria; they are also known as gram-positive bacteriocins. The high antimicrobial activity of lacticins and the continuing appearance of antibiotic-resistant bacteria in recent years have resulted in a renewed interest in lantibiotics. A partially purified form of lacticin NK34 (a Lactococcus lactis product isolated from the Korean fermented fish jeotgal) was tested to determine its antimicrobial effects against Staphylococcus aureus $(\mathrm{n}=20)$ and coagulasenegative Staphylococcus (CNS, $\mathrm{n}=20$ ) strains isolated from the raw milk of cows with subclinical bovine mastitis in the present study. The spot-on-lawn assay was used to identify the 2 strains from each group with the greatest lacticin NK34 susceptibility, and the minimal lethal dose (MLD) was measured in ICR (imprinting control region) mice. The preventive and therapeutic effects of lacticin NK34 on the mouse infection model were determined for the first time. Lacticin NK34 demonstrated antimicrobial effects in 14 of $20(70 \%)$ S. aureus indicator strains and in 18 of 20 (90\%) CNS strains. Staphylococcus aureus 69 and S. simulans 55 demonstrated the greatest susceptibility to lacticin NK34 in the spot-on-lawn assay. The $S$. aureus 69 MLD was measured at $1.53 \times 10^{9} \mathrm{cfu} /$ mouse, whereas the S. simulans 55 MLD was $3.59 \times 10^{9} \mathrm{cfu} /$ mouse. Mice infected experimentally with $S$. aureus 69 MLD or $S$. simulans 55 MLD were treated with lacticin NK34. Treated mice demonstrated an $80 \%$ survival rate $(48$ of 60 mice) compared with a survival rate of $7.5 \%$ (3 of 40 mice) in control mice treated with distilled water. These data suggest that lacticin NK34 might be useful in the control of bovine mastitis and systemic bacterial infection.

Received February 1, 2010.

Accepted April 20, 2010.

${ }^{1}$ Corresponding authors: koohj@snu.ac.kr (Hye Cheong Koo) and yhp@snu.ac.kr (Yong Ho Park)
Key words: Lactococcus lactis, lacticin NK34, bovine mastitis, bacteriocin

\section{INTRODUCTION}

Bovine mastitis is defined as udder inflammation resulting from infection or trauma. It is the most prevalent global production disease in dairy herds (Klostermann et al., 2009). According to the research done by National Veterinary Research and Quarantine Service in Korea from 2003 to 2005 (National Veterinary Research and Quarantine Service, 2007), 71.3\% (2,726/3,822) of bacterial disease cases in animals were found to be bovine mastitis. It is estimated that up to $30 \%$ of dairy cattle were affected by mastitis in Europe resulting in costs of roughly €1.55 billion in 2005, despite the implementation of mastitis control programs (SABRE, 2006).

Bovine mastitis is a major clinical problem because of the increasing presence of antibiotic-resistant bacteria and treatment failure. Modern mastitis control, therapeutic, and prophylactic methods are focused on antibiotic therapy, which is sometimes expensive and ineffective in chronic infections (Turutoglu et al., 2009). The cure rate in chronic Staphylococcus aureus mastitis cases might be as low as $4 \%$ (Barkema et al., 2006). There are growing concerns involving imprudent antibiotic use in veterinary medicine amid the emergence of antimicrobial-resistant bacterial strains (Barkema et al., 2006). In addition, many antibiotics used to treat bovine mastitis are also used in human beings. Naturally occurring antimicrobial substances including bacteriocins, bacteriophages, probiotics, and antimicrobial peptides have undergone consideration as alternative antibiotics because of the emergence of antibiotic-resistant pathogens (Gillor et al., 2004; Sit and Vederas, 2008).

Lantibiotics, or gram-positive bacteriocins, were examined for antimicrobial effects on bacteria associated with bovine mastitis. Lantibiotics are small $(<5$ $\mathrm{kDa}$ ), polycyclic peptides produced by gram-positive bacteria and are class I bacteriocins (Akçelik et al., 
2006; Gardiner et al., 2007; Bierbaum and Sahl, 2009). They contain atypical amino acids such as lanthionine, L-methyllanthionine, and several dehydrated amino acids (Asaduzzaman and Sonomoto, 2009). Many lantibiotics predate the discovery of penicillin (Lawton et al., 2007). Nisin, the first identified lantibiotic, was discovered in 1928 and has been used as a food preservative for more than $40 \mathrm{yr}$ without the development of natural resistance (Delves-Broughton et al., 1990). The presence of antimicrobial-resistant bacteria, particularly vancomycin-resistant enterococci, has led to a resurgence in lantibiotic research (Asaduzzaman and Sonomoto, 2009).

We evaluated the antimicrobial effects of the $L c$. lactis product lacticin NK34 (a nisin-like bacteriocin), isolated from jeotgal (Korean salted and fermented fish food), in our previous study (Lee et al., 2008). Lacticin NK34 supernatants demonstrated bactericidal effects against several bacterial strains associated with bovine mastitis. Lacticin NK34 was purified and demonstrated a molecular weight equivalent to that of nisin $(3.5 \mathrm{kDa})$. Polymerase chain reactions using nisin gene-specific primers revealed that lacticin NK34 had a similar sequence to the nisin $\mathrm{Z}$ gene. We therefore focused on the evaluation of partially purified lacticin NK34 against isolates of Staphylococus spp., the predominant pathogens associated with bovine mastitis, and examined the antimicrobial preventive and therapeutic effects of NK34 on murine infection with Staphylococcus spp. isolated from bovine mastitis.

\section{MATERIALS AND METHODS}

\section{Preparation of Lacticin NK34}

The lacticin NK34-producing Lc. lactis strain was isolated from jeotgal, a traditional Korean fermented fish food. Lactococcus lactis was cultured in flask containing de man, Rogosa, and Sharpe broth $(2 \mathrm{~L})$ at $35^{\circ} \mathrm{C}$ for 18 $\mathrm{h}$ (Difco Laboratories, Detroit, MI). Cells were removed by centrifugation at $12,000 \times g$ for $20 \mathrm{~min}$ at $4^{\circ} \mathrm{C}$, and supernatants were collected and then precipitated with $60 \%$ ammonium sulfate. Precipitates were collected by centrifugation at $12,000 \times \mathrm{g}$ for $25 \mathrm{~min}$ at $4^{\circ} \mathrm{C}$, resuspended in $100 \mathrm{~m} M$ phosphate buffer (pH 7.0), and dialyzed against $10 \mathrm{~m} M$ phosphate buffer ( $\mathrm{pH}$ 7.0) for $18 \mathrm{~h}$ in a Spectra-Por No. 3 dialysis tube (molecular weight cutoff of 3,500; Spectrum Medical Industries, Los Angeles, CA). The collected samples were stored at $-70^{\circ} \mathrm{C}$ after dialysis (Lee et al., 2008). Because lacticin NK34 was already proven to be a bacteriocin through our previous study, a partially purified form of lacticin NK34 was used in the present study.

\section{Preparation of Indicator Strains}

Milk samples were collected by herd owners or personnel from several Korean dairy farms. Milk samples with SCC >500,000 cells/mL were selected by using the Bentley Somacount 150 (Bentley Instruments Inc., Chaska, MN). Bacterial examination of milk samples was conducted using standard laboratory techniques according to the National Mastitis Council (Harmon et al., 1990). Selected milk samples were streaked onto $5 \%$ blood agar plates (Komed, Sungnam, Korea) and incubated at $37^{\circ} \mathrm{C}$ for 18 to $24 \mathrm{~h}$. Colonies were initially assessed by morphology and hemolysis patterns, followed by Gram staining and motility tests. Biochemical tests, such as catalase, oxidase, coagulase, growth in $6.5 \%$ or $10 \% \mathrm{NaCl}$, esculin hydrolysis, carbohydrate (glucose, mannitol, ribose, sorbitol, and trehalose) fermentation tests, biochemical reaction on MacConkey (Becton Dickinson and Co., Sparks, MD) agar, indole production, lysine decarboxylation, urease production, and citrate utilization tests were performed as required (Park et al., 2007). Gram-positive species were identified with the Vitek II (BioMérieux, Durham, NC) system (Nam et al., 2009).

\section{Spot-on-Lawn Assay Against Bovine Mastitis-Causing Bacteria}

Antimicrobial activity of lacticin NK34 was determined by using the spot-on-lawn method (Lee et al., 2000). Staphylococcus aureus $(\mathrm{n}=20)$ and CNS $(\mathrm{n}=$ 20 ) isolates served as indicator strains, and were seeded to tryptic soy agar (Difco Laboratories) and overlaid on a plate and left to solidify. Partially purified lacticin NK34 forms were serially diluted; $5 \mu \mathrm{L}$ of each dilution was spotted on plates. Plates were incubated at $37^{\circ} \mathrm{C}$ for 18 to $24 \mathrm{~h}$. Lacticin NK34 activity was determined in activity units (AU) as follows (Twomey et al., 2000): bacteriocin activity $(\mathrm{AU} / \mathrm{mL})=2^{\mathrm{n}} \times 200$, where $\mathrm{n}=$ dilution number with the smallest zone of inhibition.

\section{Determination of Minimal Lethal Dose of Bovine Mastitis-Causing Bacteria in Mice}

Bacterial strains with the greatest lacticin NK34 susceptibility $(\mathrm{n}=2)$ were selected by using the spoton-lawn assay. Both $S$. aureus and CNS strains were included, and the minimal lethal doses (MLD) were measured in ICR (imprinting control region) mice. Female ICR mice $(\mathrm{n}=60)$ were used in this study; 5 ICR mice were used for each inoculum. Six inocula (from $10^{8}$ to $10^{10} \mathrm{cfu} /$ mouse) were administered through intraperitoneal injection. Cell numbers of selected strains 


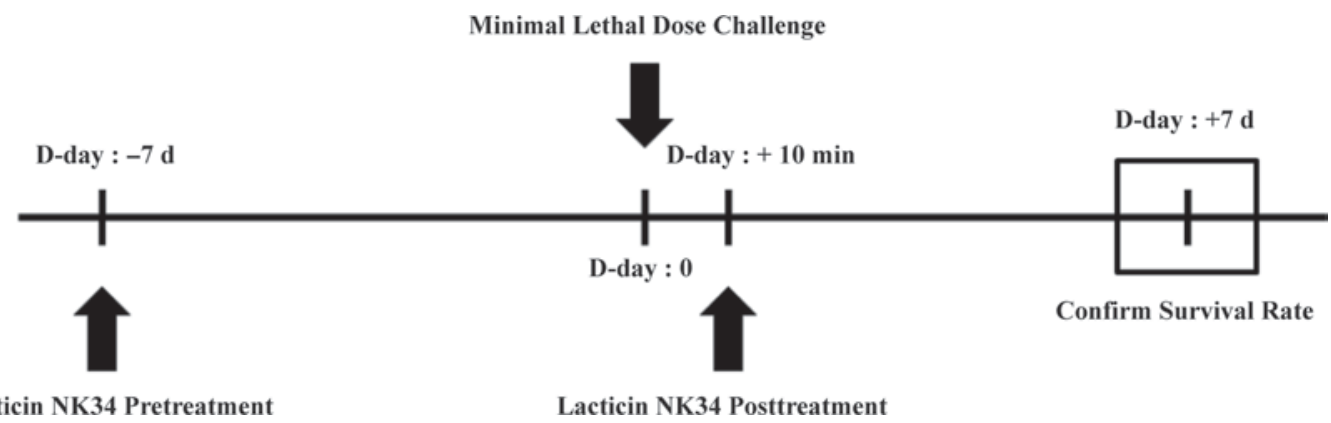

Figure 1. Schematic presentation of the in vivo experiments using partially purified lacticin NK34.

were determined by colony numbers in plate count agar. Mice mortality rates were determined for a $24-\mathrm{h}$ period. All the in vivo mouse experiments adhered to the guidelines of the care and proper use of laboratory animals set by the Seoul National University (Approval Number SNU-081030-1).

\section{Safety Test and Challenge of MLD to Lacticin-Treated ICR Mice}

Female ICR mice $(\mathrm{n}=15)$ were used for safety testing. Mice were divided into 3 equal groups, and each group was injected intraperitoneally with different concentrations of partially purified lacticin NK34. Physiological changes in mice were observed for $7 \mathrm{~d}$. Pretreatment and posttreatment tests were performed after $7 \mathrm{~d}$ if mice demonstrated no lacticin NK34 side effects. A total of 100 ICR mice were used to evaluate the antimicrobial effects of lacticin NK34. Effective concentration levels of lacticin NK34 were determined using a pilot study. Lacticin NK34 concentrations were measured through the spot-on-lawn method. Mice were divided into 3 different groups: pretreatment $(7 \mathrm{~d}$ before MLD injection), posttreatment (10 min post-MLD injection), and pre/posttreatment (pre- + posttreatment) groups were evaluated. Mortality rates of mice were observed through $7 \mathrm{~d}$ (Figure 1).

\section{RESULTS}

\section{In Vitro Antimicrobial Activity of Lacticin NK34 Against Bovine Mastitis-Causing Bacteria}

Partially purified lacticin NK34 peptide was tested against $S$. simulans isolated from subclinical bovine mastitis to ensure purification (Lee et al., 2008). The peptide was subsequently tested against additional bacterial strains associated with mastitis $(\mathrm{n}=40)$. Lacticin NK34 demonstrated antimicrobial effects against 70\% of S. aureus indicator strains (14 of 20 ) and $90 \%$ of CNS strains (18 of 20); the antimicrobial activity of lacticin
NK34 against $30 \%(6 / 20), 45 \%(9 / 20), 20 \%(4 / 20)$, and $5 \%(1 / 20)$ of $S$. aureus indicator strains was scored as negative, $+(\leq 3,200 \mathrm{AU} / \mathrm{mL}),++(3,200 \mathrm{AU} / \mathrm{mL}$ $\leq$ effect $\leq 25,600 \mathrm{AU} / \mathrm{mL})$, and $+++(\geq 25,600 \mathrm{AU} /$ $\mathrm{mL})$, respectively. For CNS strains, $10 \%(2 / 20), 70 \%$ $(14 / 20), 15 \%(3 / 20)$, and $5 \%(1 / 20)$ were observed to be negative,,+++ , and +++ , respectively.

Isolated $S$. aureus 69 and CNS 55 strains, later identified as $S$. simulans, demonstrated the strongest inhibition zone of all indicator strains. Lacticin NK34 activity units were measured against $S$. aureus 69 and S. simulans 55 (Figure 2). Lacticin NK34 was more effective against $S$. simulans 55 than against $S$. aureus 69. Activity units of lacticin NK34 were determined against $S$. aureus $69(25,600 \mathrm{AU} / \mathrm{mL})$ and $S$. simulans $55(51,200 \mathrm{AU} / \mathrm{mL})$. After confirming the activity of lacticin NK34 against selected strains, S. aureus 69 and S. simulans 55 were prepared for in vivo testing.

\section{MLD of Bovine Mastitis-Causing Bacteria Against ICR Mice}

Six inocula ranging from $3.05 \times 10^{8}$ to $3.05 \times 10^{10}$ $\mathrm{cfu} /$ mouse and $3.59 \times 10^{8}$ to $3.59 \times 10^{10} \mathrm{cfu} /$ mouse were prepared for each $S$. aureus 69 and $S$. simulans 55 injection, respectively. The MLD of $S$. aureus 69 was determined at $1.53 \times 10^{9} \mathrm{cfu} /$ mouse and that of S. simulans 55 at $3.59 \times 10^{9} \mathrm{cfu} /$ mouse after $24 \mathrm{~h}$. Staphylococcus aureus 69 injections at $7.63 \times 10^{8} \mathrm{cfu} /$ mouse resulted in the death of all mice at $72 \mathrm{~h}$. Therefore, the MLD of $S$. aureus 69 was set at $1.53 \times 10^{9}$ $\mathrm{cfu} /$ mouse.

\section{Safety Test and Challenge of MLD to Lacticin-Treated ICR Mice}

Intraperitoneal injection of partially purified lacticin NK34 demonstrated no side effects during safety testing. Therefore, the pre- and posttreatment lacticin NK34 treatment tests were performed to determine the appropriate lacticin NK34 concentration levels. 
Table 1. Comparison of survival rates of ICR (imprinting control region) mice in different treatment groups

\begin{tabular}{lcc}
\hline & \multicolumn{2}{c}{$\begin{array}{c}\text { Challenge strain, no. survivors/ } \\
\text { no. challenged after } 7 \mathrm{~d}\end{array}$} \\
\cline { 2 - 3 } Group $^{1}$ & $\begin{array}{c}\text { Staphylococcus } \\
\text { aureus } 69\end{array}$ & $\begin{array}{c}\text { Staphylococcus } \\
\text { simulans } 55\end{array}$ \\
\hline Lacticin NK34 & & \\
Pretreatment & $8 / 10$ & $12 / 15$ \\
Posttreatment & $7 / 10$ & $13 / 15$ \\
Pre-/ & $3 / 5$ & $5 / 5$ \\
posttreatment & & \\
Control & $0 / 5$ & $1 / 5$ \\
Pretreatment & $0 / 5$ & $0 / 5$ \\
Posttreatment & $1 / 10$ & $1 / 10$ \\
No treatment &
\end{tabular}

${ }^{1}$ Treatment groups were divided into pretreatment $[7 \mathrm{~d}$ before minimal lethal dose (MLD) injection], posttreatment (10 min after MLD injection), and pre-/posttreatment groups to determine the preventative and therapeutic effects of lacticin NK34 on mice. Control = treatment with distilled water.

Injections were administered at 2,560, 5,120, 7,680, and $10,240 \mathrm{AU} /$ mouse to mice already challenged with the $S$. aureus 69 isolate. Mice injected with 7,680 and $10,240 \mathrm{AU}$ demonstrated the same survival rate; therefore, 7,680 AU/mouse was selected as the concentration for treatment injection for challenge tests. Lacticin NK34-treated mice demonstrated an 80\% (48 of 60) survival rate compared with a survival rate of $7.5 \%$ (3 of 40) survival rate for control mice (treated with distilled water) through d 7 of observation (Table 1). Different lacticin NK34 injection groups (pretreatment, posttreatment, and pre/post treatment) did not demonstrate significant differences in survival rate. Most mice that did not survive died within $24 \mathrm{~h}$.

\section{DISCUSSION}

Lantibiotics have widespread antimicrobial effects and may serve as promising substitutes for antibiotics. Applications of lantibiotics in both human and veterinary clinical therapies have been evaluated (Ryan et al., 2002). Prominent lantibiotics include nisin and lacticin 3147 (effective against bacterial mastitis and enterococcal infections), mersacidin (antimicrobial against $S$. aureus and methicillin-resistant Staphylococcus aureus, bacterial mastitis, oral decay, and acne), and gallidermin and epidermin (effective against acne, eczema, folliculitis, and impetigo). Lacticin NK34 cell-free supernatants demonstrated a relatively broad spectrum of activity against various bacteria, yeasts, and molds in our previous study (Lee et al., 2000). Lacticin NK34 also proved to have strong antimicrobial activity against vancomycin-resistant Enterococcus faecium, Listeria monocytogenes, and Bacillus cereus (data not shown). Partially purified lacticin NK34 was only tested against a limited number of gram-positive bovine mastitis-causing bacteria in the present study because this study focused on staphylococci because of their abundance and low cure rate, and the emergence of $\mathrm{CNS}$ as a predominant pathogen associated with bovine mastitis (Santos et al., 2008). Partially purified lacticin NK34 showed variable bactericidal effects against different $S$. aureus isolates from bovine mastitis in the present study, and other researchers have reported variable levels of bactericidal effects of nisin against S. aureus strains (Cao et al., 2007; Arqués et al., 2008; Piper et al., 2009; Prado-Acosta et al., 2010).

The MLD of isolated strains $S$. aureus 69 and $S$. simulans 55 were measured for accurate in vivo testing. The MLD of $S$. aureus $69,1.53 \times 10^{9} \mathrm{cfu} /$ mouse in the present study, was similar to that measured in a previous study (Chatterjee et al., 1992). In contrast, injection of encapsulated S. simulans (isolated from a clinical case of bovine mastitis) at $5 \times 10^{8} \mathrm{cfu} /$ mouse demonstrated no lethal effects after $48 \mathrm{~h}$ (Anderson and Wilson, 1981). However, S. simulans 55 demonstrated some lethal effects not only at $8.97 \times 10^{8} \mathrm{cfu} /$ mouse but also at $4.48 \times 10^{8} \mathrm{cfu} /$ mouse in the present study. Moreover, partially purified lacticin NK34 was effective against this $S$. simulans 55 isolate in the present study.

Many lantibiotics have been evaluated against the mouse infection model. Mice injected with mutacin B-Ny266 (produced by Staphylococcus mutans Ny266) immediately after bacterial injection demonstrated a mortality rate of zero, whereas mice injected with methicillin-resistant S. aureus had a 70 to $100 \%$ mortality rate (Mota-Meira et al., 2005). Most well-known lantibiotic nisins have antimicrobial effects against gram-positive bacteria through in vivo testing (Gold-
A)

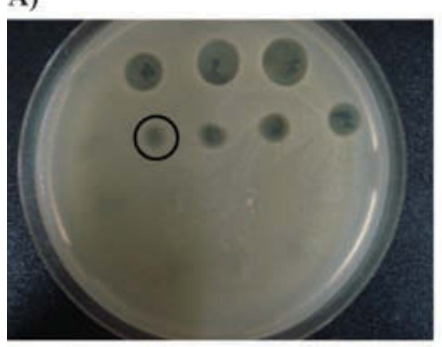

Staphylococcus aureus 69 $2^{7} \times 200=25,600 \mathrm{AU} / \mathrm{mL}$
B)

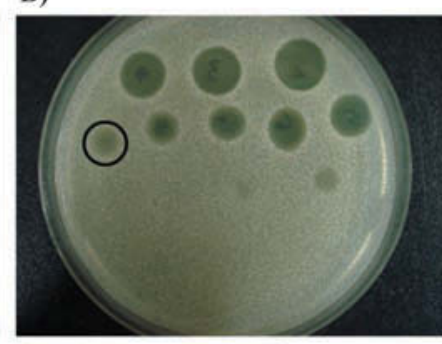

Staphylococcus simulans 55 $2^{8} \times 200=51,200 \mathrm{AU} / \mathrm{mL}$
Figure 2. Antimicrobial activity of lacticin NK34 against Staphylococcus aureus 69 (A) and Staphylococcus simulans 55 (B) using the spot-on-lawn assay. Activity of lacticin NK34 against $S$. aureus 69 and $S$. simulans 55 was 25,600 activity units (AU)/mL and 51,200 $\mathrm{AU} / \mathrm{mL}$, respectively. Encircled spots indicate the final dilutions demonstrating inhibition of bacterial growth. Color version available in online PDF. 
stein et al., 1998); some effects were stronger than antibiotic effects. The in vivo activity of mersacidin against both the methicillin-sensitive $S$. aureus SG 511 and the methicillin-resistant strains (S. aureus E 710 and $S$. aureus $\mathrm{C} 31155$ ) was superior to that of vancomycin in a previous study (Chatterjee et al., 1992).

The primary focus of the present study was to assess the effects of lacticin NK34 against an in vivo mouse infection model. Lacticin NK34 was shown, for the first time, to be effective in vivo against bacterial infection in the present study. Lacticin NK34 demonstrated 80\% survival in the present study, suggesting strong antimicrobial effects against bacteria associated with bovine mastitis both in vivo and in vitro.

Lacticin 3147 is used in teat dips and seals for the prevention of bovine mastitis (Ryan et al., 1998; Twomey et al., 2000; Crispie et al., 2005). Nisin is used in Wipe Out Dairy Wipes (AMBI, later ImmuCell, Portland, ME; Cotter et al., 2005). Results from the present study suggest that lacticin NK34 may be useful in the control and prevention of bovine mastitis. Future studies should evaluate effective lacticin NK34 concentrations and the mechanisms of lacticin NK34 antimicrobial activity.

\section{ACKNOWLEDGMENTS}

This study was supported by the National Veterinary Research and Quarantine Service (Z-AD13-2007-0802). Additional support was provided by the Korean Research Foundation Grant (KRF-2008-531-E00076), the Research Institute of Veterinary Science, Department of Veterinary Microbiology, College of Veterinary Medicine, and the BK21 Program for Veterinary Science, Seoul National University.

\section{REFERENCES}

Akçelik, O., C. Tükel, G. Ozcengiz, and M. Akçelik. 2006. Characterization of bacteriocins from two Lactococcus lactis ssp. lactis isolates. Mol. Nutr. Food Res. 50:306-313.

Anderson, J. C., and C. D. Wilson. 1981. Encapsulated, coagulasenegative strain of Staphylococcus simulans. Infect. Immun. 33:304-308.

Arqués, J. L., E. Rodríguez, M. Nuñez, and M. Medina. 2008. Antimicrobial activity of nisin, reuterin, and the lactoperoxidase system on Listeria monocytogenes and Staphylococcus aureus in cuajada, a semisolid dairy product manufactured in Spain. J. Dairy Sci. 91:70-75.

Asaduzzaman, S. M., and K. Sonomoto. 2009. Lantibiotics: Diverse activities and unique modes of action. J. Biosci. Bioeng. 107:475487.

Barkema, H. W., Y. H. Schukken, and R. N. Zadoks. 2006. Invited Review: The role of cow, pathogen, and treatment regimen in the therapeutic success of bovine Staphylococcus aureus mastitis. J. Dairy Sci. 89:1877-1895.

Bierbaum, G., and H. G. Sahl. 2009. Lantibiotics: mode of action, biosynthesis and bioengineering. Curr. Pharm. Biotechnol. 10:218.
Cao, L. T., J. Q. Wu, F. Xie, S. H. Hu, and Y. Mo. 2007. Efficacy of nisin in treatment of clinical mastitis in lactating dairy cows. J. Dairy Sci. 90:3980-3985.

Chatterjee, S., D. K. Chatterjee, R. H. Jani, J. Blumbach, B. N Ganguli, N. Klesel, M. Limbert, and G. Seibert. 1992. Mersacidin, a new antibiotic from Bacillus. In vitro and in vivo antibacterial activity. J. Antibiot. (Tokyo) 45:839-845.

Cotter, P. D., C. Hill, and R. P. Ross. 2005. Bacterial lantibiotics: Strategies to improve therapeutic potential. Curr. Protein Pept. Sci. 6:61-75.

Crispie, F., D. Twomey, J. Flynn, C. Hill, P. Ross, and W. Meaney 2005. The lantibiotic lacticin 3147 produced in a milk-based medium improves the efficacy of a bismuth-based teat seal in cattle deliberately infected with Staphylococcus aureus. J. Dairy Res. 72:159-167.

Delves-Broughton, J., P. Blackburn, R. J. Evans, and J. Hugenholtz. 1990. Applications of the bacteriocin, nisin. Antonie van Leeuwenhoek 69:193-202.

Gardiner, G. E., M. C. Rea, B. O'Riordan, P. O'Connor, S. M. Morgan, P. G. Lawlor, P. B. Lynch, M. Cronin, R. P. Ross, and C. Hill. 2007. Fate of the two-component lantibiotic lacticin 3147 in the gastrointestinal tract. Appl. Environ. Microbiol. 73:7103-7109.

Gillor, O., B. C. Kirkup, and M. A. Riley. 2004. Colicins and microcins: The next generation antimicrobials. Adv. Appl. Microbiol. 54:129-146.

Goldstein, B. P., J. Wei, K. Greenberg, and R. Novick. 1998. Activity of nisin against Streptococcus pneumoniae, in vitro, and in a mouse infection model. J. Antimicrob. Chemother. 42:277-278.

Harmon, R. J., R. J. Eberhart, D. E. Jasper, B. E. Langlois, and R. A. Wilson. 1990. Microbiological procedures for diagnosis of bovine udder infection. National Mastitis Council Inc., Arlington, VA.

Klostermann, K., F. Crispie, J. Flynn, W. J. Meaney, R. Paul Ross, and C. Hill. 2009. Efficacy of a teat dip containing the bacteriocin lacticin 3147 to eliminate Gram-positive pathogens associated with bovine mastitis. J. Dairy Res. 29:1-8.

Lawton, E. M., R. P. Ross, C. Hill, and P. D. Cotter. 2007. Twopeptide lantibiotics: A medical perspective. Mini Rev. Med. Chem. 7:1236-1247.

Lee, N. K., S. A. Jun, J. U. Ha, and H. D. Paik. 2000. Screening and characterization of bacteriocinogenic lactic acid bacteria from jeot-gal, a Korean fermented fish food. J. Microbiol. Biotechnol. 10:423-428.

Lee, N. K., Y. L. Park, H. W. Kim, Y. H. Park, S. L. Rhim, J. M. Kim, J. M. Kim, H. M. Nam, S. C. Jung, and H. D. Paik. 2008. Purification and characterization of lacticin NK34 produced by Lactococcus lactis NK34 against bovine mastitis. Korean J. Food Sci. Ani. Resour. 28:457-462.

Mota-Meira, M., H. Morency, and M. C. Lavoie. 2005. In vivo activity of mutacin B-Ny266. J. Antimicrob. Chemother. 56:869-871.

Nam, H. M., S. K. Lim, H. M. Kang, J. M. Kim, J. S. Moon, K. C. Jang, J. M. Kim, Y. S. Joo, and S. C. Jung. 2009. Prevalence and antimicrobial susceptibility of gram-negative bacteria isolated from bovine mastitis between 2003 and 2008 in Korea. J. Dairy Sci. 92:2020-2026.

National Veterinary Research and Quarantine Service. 2007. Pages 15-27 in Conference data for evaluating domestic animal infectious disease in 3rd quarter of 07. NVRQS, Anyang, Korea.

Park, Y. K., H. C. Koo, S. H. Kim, S. Y. Hwang, W. K. Jung, J. M. Kim, S. Kim, R. T. Shin, and Y. H. Park. 2007. The analysis of milk components and pathogenic bacteria isolated from bovine raw milk in Korea. J. Dairy Sci. 90:5405-5414.

Piper, C., L. A. Draper, P. D. Cotter, R. P. Ross, and C. Hill. 2009. A comparison of the activities of lacticin 3147 and nisin against drug-resistant Staphylococcus aureus and Enterococcus species. J. Antimicrob. Chemother. 64:546-551.

Prado-Acosta, M., S. M. Ruzal, M. C. Allievi, M. M. Palomino, and C. Sanchez Rivas. 2010. Synergistic effects of the Lactobacillus acidophilus surface layer and nisin on bacterial growth. Appl. Environ. Microbiol. 76:974-977.

Ryan, M. P., C. Hill, and R. P. Ross. 2002. Exploitation of lantibiotic peptides for food and medical uses. Pages 193-242 in Peptide 
Antibiotics - Discovery, Modes of Action, and Applications. C. J. Dutton, M. A. Haxell, H. A. McArthur, and R. G. Wax, ed. Marcel Dekker, New York, NY.

Ryan, M. P., W. J. Meaney, R. P. Ross, and C. Hill. 1998. Evaluation of lacticin 3147 and a teat seal containing this bacteriocin for inhibition of mastitis pathogens. Appl. Environ. Microbiol. 64:2287-2290.

SABRE. 2006. Cutting edge genomics for sustainable animal breeding. In Framework 6 Report. G. Faraday, ed. Farm Animal Genetics and Genomics Faraday Partnership Ltd., Edinburgh, UK.

Santos, O. C., E. M. Barros, M. A. Brito, C. Bastos Mdo, K. R Dos Santos, and M. Giambiagi-Demarval. 2008. Identification of coagulase-negative staphylococci from bovine mastitis using RFLP-PCR of the groEL gene. Vet. Microbiol. 130:134-140.
Sit, C. S., and J. C. Vederas. 2008. Approaches to the discovery of new antibacterial agents based on bacteriocins. Biochem. Cell Biol. 86:116-123.

Turutoglu, H., M. Hasoksuz, D. Ozturk, M. Yildirim, and S. Sagnak. 2009. Methicillin and aminoglycoside resistance in Staphylococcus aureus isolates from bovine mastitis and sequence analysis of their mecA genes. Vet. Res. Commun. 33:945-956.

Twomey, D. P., A. I. Wheelock, J. Flynn, W. J. Meaney, C. Hill, and R. P. Ross. 2000. Protection against Staphylococcus aureus mastitis in dairy cows using a bismuth-based teat seal containing the bacteriocin, lacticin 3147. J. Dairy Sci. 83:1981-1988. 